\title{
Generation of electric energy using natural water affluent through the design of a pelton turbine prototype
}

\section{Generación de energía eléctrica usando afluente de agua natural mediante el diseño de un prototipo de turbina}

\author{
ALONSO-GAETA, Reynaldo †*, AGUILAR-GONZÁLEZ, Alma Leticia, ZUÑIGA-NERIA, \\ Capistrano and CASARRUBIAS-GUERRERO, Gabriel
}

Instituto Tecnológico Superior de Ciudad Hidalgo

ID $1^{\text {st }}$ Author: Reynaldo, Alonso-Gaeta / ORC ID: 0000-0001-6430-217X, CVU CONACYT ID: 371734

ID $1^{\text {st }}$ Coauthor: Alma Leticia, Aguilar-González / ORC ID: 0000-0002-0611-1815, CVU CONACYT ID: 690744

ID $2^{\text {nd }}$ Coauthor: Capistrano, Zuñiga-Neria / ORC ID: 0000-0003-0405-4455, CVU CONACYT ID: 446064

ID $3^{\text {rd }}$ Coauthor: Gabriel, Casarrubias-Guerrero / ORC ID: 0000-0003-4775-0725, CVU CONACYT ID: 389684

DOI: $10.35429 / J A N R E .2019 .5 .3 .18 .22$

Received October 14, 2019; Accepted December 03, 2019

\begin{abstract}
Agriculture in Mexico is an economic activity that allows for the livelihood of the most vulnerable families. However, the economic development of producers is reduced by the energy costs generated at work. For this reason, a prototype of Pelton turbine specially designed to take advantage of the natural fall of water was developed; in this way, clean energy is used for the same agricultural activity. The prototype results in a low-cost solution to reduce energy costs for small Mexican agricultural producers. The prototype is designed for a non-industrial water affluent but natural fall, the prototype was field tested, measuring performance results and having a substantial contribution to possible energy saving.
\end{abstract}

Turbine, Generation of energy, Clean energy

\begin{abstract}
Resumen
La agricultura en México es una actividad económica que permite llevar el sustento a las familias más vulnerables, sin embargo el desarrollo económico de los productores se ve mermado por los gastos energéticos que se generan en la labor, es por esta razón que se desarrolló un prototipo de turbina Pelton diseñada especialmente para aprovechar la caída de agua natural y así aprovechar la energía que esta caída a través del prototipo puede generar, de esta manera se genera energía limpia que se utiliza en artículos propios para la misma actividad agrícola, el prototipo viene a ser una opción de solución a bajo costo para disminuir gastos energéticos en productores agrícolas pequeños Mexicanos. El prototipo está diseñado para una afluente no industrial de agua sino caída natural, el prototipo fue probado en campo midiendo resultados de rendimiento teniendo una contribución sustancial a un posible ahorro energético.
\end{abstract}

Citation: ALONSO-GAETA, Reynaldo, AGUILAR-GONZÁLEZ, Alma Leticia, ZUÑIGA-NERIA, Capistrano and CASARRUBIAS-GUERRERO, Gabriel. Generation of electric energy using natural water affluent through the design of a pelton turbine prototype. Journal-Agrarian and Natural Resource Economics. 2019 3-5: 18-22

\footnotetext{
* Correspondence to Author (email: ralonso@itsch.edu.mx)

$\dagger$ Researcher contributing as first author.
} 


\section{Introduction}

Pelton turbines are hydraulic machines capable of generating electrical energy by circular movement of their blades, commonly known as spoons. This movement is generated through a stream of fluid that falls directly into the blades and the force of impact, this means that the pressure with which the fluid leaves the pipe will be the same that moves the blades, which in turn, will move a rotor or shaft attached to a chain or band that will move the generator that, when connected to another instrument, tool or machinery, will be turned on, without the need of household electric current or provided by the Federal Electricity Commission. Thus, the use of hydraulic machines for electric power generation is a source of cheap, clean and pollution-free energy.

For the creation of a hydraulic machine, fluid analysis is needed, in order to understand the condition of the pipes.

A Pelton Turbine is not an old machine that will cease to be used because it is inefficient or unnecessary, it was discontinued due to the fact that using fossil fuel granted an increase in the economy of every country, since this is difficult to extract, among other things, it had a very high value. There is a theory that the use of clean energy generated from the elements is even more expensive than that of fossil waste and it could certainly be priced higher but not precisely for the right reasons. This factor is variable with respect to the market and the facilities of rulers, since knowing that the use of these machines (among others that are not precisely hydraulic but also wind-based, thermoelectric, etc.) will reduce the electrical consumption of inhabitants provided by government agencies, which will generate losses in the economy of the country, or at least that is what people believe, and in this way, clean energy generating machines have increased in price, also due to the inflation in the country.

In consideration of our rational thinking, we believe that the machines previously proposed to generate energy can be used today, since oil and other resources for the generation of electricity will be exhausted one day, as a result of one of the most important phenomena which has been increasing year after year, that is, overpopulation.
Thus, measures should be taken to generate electricity in other ways, and when the entire resource has been exhausted, then, it is better to start from this moment to take preventive measures and not at some point turn to corrective actions.

\section{Background}

Observing the increase in electricity rates, as well as the inflation in the country due to the rise in the oil prices, which we export cheap and import expensive, we look for a sustainable solution using hydraulic machines previously used to generate electricity in an economic way, as a measure to reinforce jobs that require the use of electrical energy in the industrial process of floriculture; and more than just making use of these resources, we consider the decrease in pollution.

We do not know exactly who, where or how long ago people began to take advantage of the force and energy of a fluid stream; however, it is considered that the inspiration came when irrigation was known.

In ancient times, various means were used to raise the fluid of rivers to a height greater than that of its margins, from where it would run through ducts and ditches to the fields. The Persian or saqia wheel is known as an example of this. It consists on a large wheel mounted on a horizontal axis with spoons on its periphery. These wheels can still be seen working in Egypt, coupled to gears and moved by a buffalo, donkey or camel; thanks to the observation made when unhooking the mobile unit, which was some kind of animal, the movement of the wheel still persisted, so people considered that the fluid had its own energy.

The Romans knew and used hydraulic wheels as a source of mechanical force for their wheat mills, even though they did not exploit the energy of the fluid stream extensively.

The most used hydraulic wheels that worked mainly through the weight of the fluid, being the most functional and convenient, were also the first turbines that men built. The first hydraulic wheels were possibly built in Asia, China and India, about 2,200 years ago; from Asia, they went to Egypt and from there to Europe, after 700 years and later to America. 
The best inventors of the time, such as Leonardo Da Vinci, Galileo and Descartes, among others, conducted mathematical theoretical studies on hydraulic wheels. Parent, a French physicist and mathematician from Paris and a member of the Royal Academy of Sciences, studied for the first time the operation of the hydraulic wheels and correctly anticipated that there is a relationship between the speed of the wheel and the speed of the fluid. By improving the common wheels, the construction of the impulse and reaction wheels resulted in the advantage of using kinetic energy and, with this, reducing their size. The following figures show the main types of hydraulic wheels and their evolution in accordance to their uses.

\section{Problem Statement}

As a fundamental part in the use of renewable energies for implementation in the economy of the country, we considered reusing hydraulic turbines in our region, since we can assert that the uses of fossil fuel energies among others in our country have increased numerically every day.

\section{Objective}

To build a Pelton Turbine in order to assist in floriculture systems.

\section{Justification}

It consists of the creation of a Pelton Turbine to generate energy using a renewable and inexhaustible fluid, whether it comes from rivers, lakes, lagoons, waterfalls, among other water sources on the planet, in order to cut back on the consumption of electrical energy of any industry or business, as well as to create awareness in the community regarding excessive use of electrical energy.

\section{Scope and limitations}

Within the expected scope is the fumigation pump to power, so our turbine should generate at least a total of $12 \mathrm{v}$, which will power the pump and, in case of having higher voltage, this would be responsible for charging the batteries that would be integrated into the turbine, which solves one of our limitations related to the fluid, since it does not run daily and by also storing the energy, we assume that the times in which the turbine would be used may not be the same for the pump.
In our scopes we can list the results of the tests:

$$
\begin{array}{ll}
\text { 1. } & 6 \mathrm{~V} \text { to } 1 \mathrm{~A} \\
\text { 2. } & 16 \mathrm{~V} \text { to } 2 \mathrm{~A} \\
\text { 3. } & 20 \mathrm{~V} \text { to } 3 \mathrm{~A}
\end{array}
$$

Considering as a conclusion that this will power the stationary fumigation pump, but, in turn, a problem arises related to the load circuit, which was designed for a maximum of $16 \mathrm{~V}$ and having the final results, this would not be adequate and other measures would be necessary.

\section{Hypothesis}

The design of the Pelton Turbine will be adequate to power a stationary fumigation pump of $13 \mathrm{~V}$, or at least, to charge the battery.

\section{Methodology}

\section{Place:}

The research project was carried out in the municipality of Tuxpan in the town called Lombardía de Guadalupe, thanks to its people who plant flowers, peaches and avocados, they allowed us to conduct our study in the flower greenhouses. We use the irrigation fluid from the greenhouses for the implementation of the machine..

\section{Construction:}

$\begin{array}{ll}- & 5 \mathrm{~mm} \text { steel sheet } \\ - & 5.6 \mathrm{~cm} \text { plate } \\ - & \text { Forks } \\ - & \text { Engine } \\ - & \text { Steel rotor } \\ - & \text { Screws } \\ - & \text { Welding } \\ - & \text { Batteries } \\ - & \text { Components for load circuit } \\ - & \text { Motorcycle or bicycle chain or bands } \\ - & \text { Metal gears } \\ - & \text { Cables }\end{array}$

ALONSO-GAETA, Reynaldo, AGUILAR-GONZÁLEZ, Alma Leticia, ZUÑIGA-NERIA, Capistrano and CASARRUBIAS-GUERRERO, Gabriel. Generation of electric energy using natural water affluent through the design of a pelton turbine prototype. Journal-Agrarian and Natural Resource Economics. 2019 


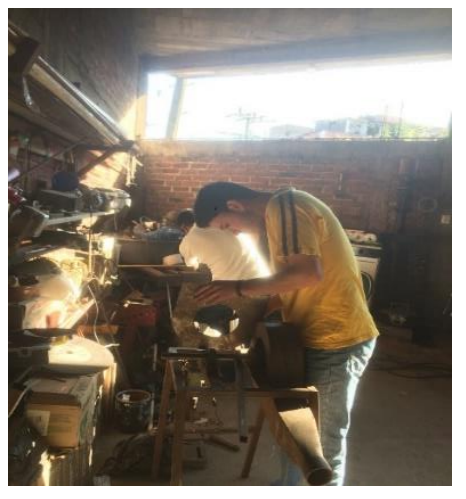

Figure 1 Turbine Construction

\section{Start up:}

To perform the field test, it was necessary to check the fluid that ran through the irrigation channel from which the fluid would be taken. For this, we made sure that they did not have any dam that would obstruct the passage of the fluid.

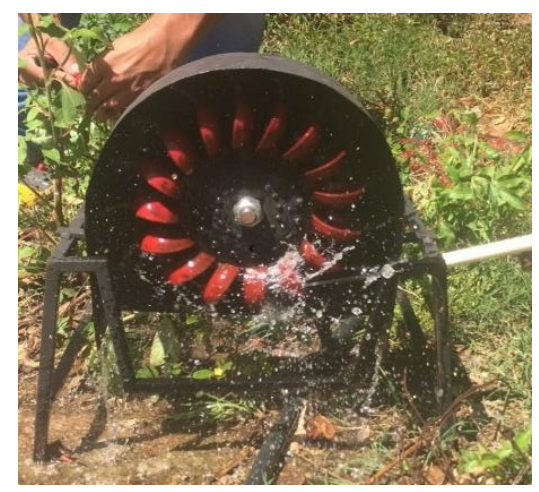

Figure 2 Start-up of Pelton turbine test 1

The second test differs from the first test because it was performed in another location, thus changing the factors obtained in test 1 . To begin with this test, we needed to check that the hoses were installed in the irrigation channel from where it would be taken and that the pipes were not blocked. As we learned from test 1 and its mistakes, we learned how to make the correct couplings in our reductions to avoid leaks, but still, without considering important aspects such as the falling pressure, among other things, we found leaks in the different couplings, hence reducing the pressure obtained at the outlet.

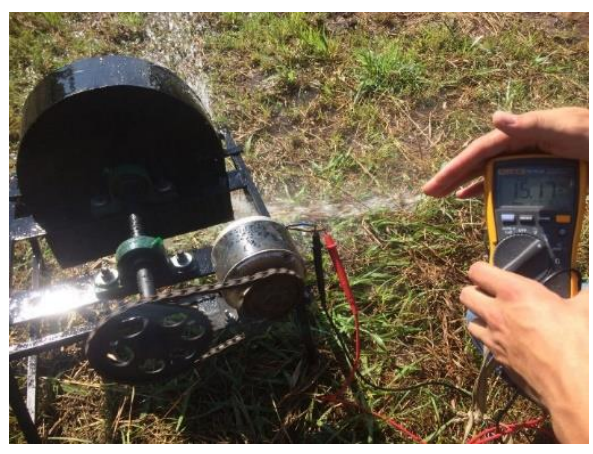

Figure 3 Start-up of Pelton turbine test 2

\section{Results}

The following voltage results were obtained after conducting the experimental investigation. We considered several aspects to reach these results, such as the elevation of the pipes, the distance and the pressure; we should have considered these aspects since for better experimentation and analysis of our results.

\section{First test:}

The pressure we measured with the pressure gauge before connecting the nozzle to our turbine was 20PSI, when analyzing the amount of pressure we had, we concluded that this would not be enough to lift our turbine, or that it would not be enough to generate the 13 volts necessary to feed the fumigation pump, this would mean that our hypothesis would not be satisfied by this pressure.

Another aspect that should be considered is the elevation and distance that we have from the intake of our fluid through the hoses until the end of the nozzle attached to the Turbine. In this first test, the distance was of approximately $50 \mathrm{~m}$ from the dam, so that the flow was greater and thanks to the reductions of the pipes the pressure would increase, until it reached the turbine.

These data, obtained before taking the measurements with our multimeter, showed us that the factors did not meet the requirements and therefore would not comply with the established hypothesis.

\section{Second test:}

Our final pressure was greatly increased, obtaining a total of 40PSI at this location, which, compared to the initial test, was doubled. The conclusion established in test 2 was recognizing the importance of distance and elevation to increase pressure.

\section{Third test:}

This section will show the third test that was carried out in the field. On this occasion, and having done previous tests, we got experimental learning from the mistakes previously made, such as the loss of flow, which is the amount of liquid that is obtained in a pipe, this can be obtained through the area with respect to speed, but for a better experimental understanding we used volume over time.

ALONSO-GAETA, Reynaldo, AGUILAR-GONZÁLEZ, Alma Leticia, ZUÑIGA-NERIA, Capistrano and CASARRUBIAS-GUERRERO, Gabriel. Generation of electric energy using natural water affluent through the design of a pelton turbine prototype. Journal-Agrarian and Natural Resource Economics. 2019 
We also mentioned the loss of pressure, which could be lost through leaks in the connections and couplings of the pipes. Another aspect considered in this test was the garbage that entered our pipe, which could be causing clogging and thus prevent the liquid from flowing correctly and even generate pressure at other points and cause breakage. This was solved by installing in the dam a wire fence with very small dimensions, that is, in what would be our tank.

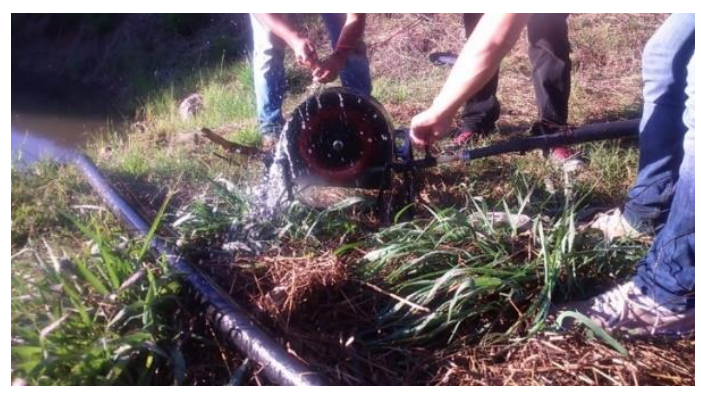

Figura 4 Puesta en marcha turbina Pelton prueba 3

For the current test, we made the final improvements to our Turbine, which are:

Integration of batteries for charging; The 12 volt batteries were integrated so as to not necessarily activate the Pelton Turbine to use the fumigation pump. These would be charged by operating the instrument and, in turn, the pump could still be powered.

Protective cover; This cover is responsible for covering the turbine to avoid fluid losses, since water impacts the cover, it falls through the walls and is introduced again into the irrigation channel or well in which it is installed.

For the installation of the batteries, a charging circuit must be assigned; this was created by analog electronics, a subject taken during this semester. The circuit that we prepared was an indicator of two states, which was developed for a maximum of 16 volts and a minimum of 3 volts, since we obtained these data in the previous tests.

\begin{tabular}{|l|r|r|r|}
\hline & $\mathbf{1}^{\mathbf{a}}$ prueba & $\mathbf{2}^{\mathbf{a}}$ prueba & $\mathbf{3}^{\mathbf{a}}$ prueba \\
\hline Distancia & $500 \mathrm{~m}$ & $500 \mathrm{~m}$ & $500 \mathrm{~m}$ \\
\hline Presión & $20 \mathrm{PSI}$ & $40 \mathrm{PSI}$ & $50 \mathrm{PSI}$ \\
\hline Voltaje & $6 \mathrm{~V}$ & $16 \mathrm{~V}$ & $20 \mathrm{~V}$ \\
\hline Corriente & $1 \mathrm{~A}$ & $2 \mathrm{~A}$ & $3 \mathrm{~A}$ \\
\hline Potencia & $6 \mathrm{~W}$ & $32 \mathrm{~W}$ & $60 \mathrm{~W}$ \\
\hline
\end{tabular}

Tabla 1 Resultados de pruebas

\section{Voltaje obtenido por prueba}

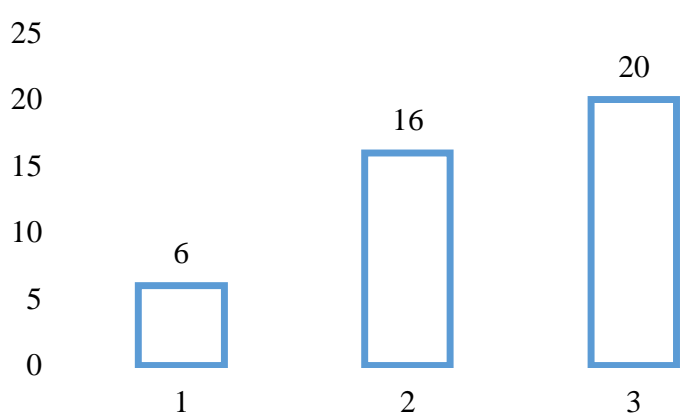

Graph 1 Voltage obtained per test

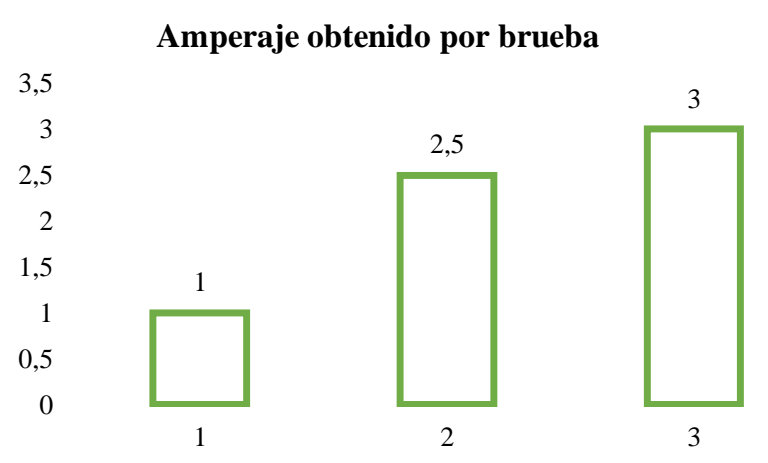

Gráfico 2 Amperaje obtenido por prueba

\section{Conclusions}

From the tests carried out during the implementation of this project, we can state that through the designed Pelton turbine sufficient electrical energy was generated to supply a small producer; however, everything should be considered by the scale of the prototype and the water effluent. In conclusion, the prototype is ideal for generating electricity in the conditions already presented.

\section{References}

Mataix, C. (2012). Mecánica de fluidos y maquinas hidráulicas. Mexico. Alfaomega

Mott R. (2006). Mecánica de fluidos. Mexico. Pearson

Wildi, T. (2007). Máquinas eléctricas y sistemas de potencia. Mexico. Pearson 